\title{
Android Based Mind Mapping Learning Media to Improve Students' Understanding of National Income
}

\author{
Syaiful Bagus Rahmadi Harahap \\ Departement of Economics, Universitas Negeri Surabaya \\ Email: syaifulbrharahap@gmail.com \\ Muhammad Abdul Ghofur \\ Departement of Economics, Universitas Negeri Surabaya \\ Email: muhammadghofur@unesa.ac.id
}

\begin{abstract}
The purpose of this study was to develop an Android-based mind mapping learning media for national income material to improve students' understanding of IPS Class XI specialization. This Development Research uses Analysis, Design, Development, Implementation, and Evaluation. Based on the results of trials that can be obtained that understood by students increases. The pre-test and post-test results increased by $30.6 \%$, and the test results prove a statistically significant difference. The implications of this study confirm the application of the concept of mind mapping in interactive learning media that helps improve student learning outcomes, especially in material with complex concept construction.
\end{abstract}

Keywords: learning media, mind mapping, interactive media, national income, student understanding

\section{INTRODUCTION}

The rapid development of science and technology has had many significant impacts in various fields. One effect of these developments in the field of education. Many learning and school management have started to get essential benefits from technological sophistication. Technology plays a role in providing convenience for teachers for practical, exciting and flexible learning activities.

Observations made by researchers at Driyorejo 1 Public High School found the fact that learning in the classroom is currently still dominated by activities that use narrative learning media. Learning still relies on narrative textbooks. Although textbooks have many advantages, especially in terms of practicality in use, the narrative nature is sometimes unable to be used to stimulate student activity. Complex and sophisticated concepts are also often difficult to convey with narrative media, especially on National Income material. This material indicated to be one of the most challenging content for students to understand in economics class.

The material of national income is basic competencies (Kompetensi Dasar / KD) 3.1 material, which analyzes the concept and method of calculating national income consisting of six sub-chapters. Including understanding national income, national income benefits, components of national income, methods of calculating national income, per capita income, and national income distribution. In this material, there are material characteristics that require different understandings because there are material that is definitive, understanding of concepts until the calculations are quite complex for beginner learners. 
The complex and intricate characteristics of the material need to be conveyed in greater depth and must be accompanied by an assessment to provide appropriate feedback. Also it requires a lot of time because they have to be gradual and sometimes need repetition. The demand compared to the allocation of teaching hours which is only three meetings with six times face to face where each time face to face is only given an allocation of two hours of study. The allocation of time felt to be lacking. This limitation can cause learner understanding is not optimal. The results of daily tests of students of class XI IPS 2 in the national income chapter show this indication. It is known that only three of the 36 students in the class have successfully achieved a minimum grade.

During this time, students only get learning that dominated by material from the available textbooks. In doing repetition and independent learning, students are also not much apart from the book. Additional media is needed to accommodate various learning needs.

Training facilities, self-stimulation learning, and lighters towards additional reference sources are needed. One alternative that is considered most appropriate is to develop supporting learning tools that are interactive and remain mobile. Android-based learning media is an essential consideration because the use of android-based learning media is one of the learning styles in the 21st century (Calimag et al., 2014).

The use of interactive media is considered able to improve the performance of students and allows students to learn whenever and wherever with interesting applications (Squire, 2013). In line with what was stated by Forment \& Guerrero (2008) that mobile-based media is flexible and can be used repeatedly with high-frequency levels. Thus it can contribute significantly to improving students' understanding. The use of technology that integrated into learning expected to be able to have a positive impact on the achievement of student learning goals. Learning media assisted by Information and Communication Technology can help make learning more exciting and have a positive effect on academic performance in the form of student learning outcomes (Chuang, 2014).

This innovative development of learning media that is interactive based on mind mapping is in line with the thought of Dasna (2015) which states that interactive learning refers to the interaction between students and educators, students with teachers, or also students with media/resources learning. This innovative development of learning media that is interactive based on mind mapping is in line with the thought of Dasna (2015) which states that interactive learning refers to the interaction between students and educators, students with teachers, or also students with media/resources learning. This thinking also supported by Louisel \& Descamps (Majid, 2014). They argue that in the concept of mind mapping has three main objectives, namely increasing the level of student thinking, checking student understanding, and increasing 
student participation. Based on these reasons, researchers try to develop interactive teaching materials packaged in mind mapping based learning media.

Buzan (2013) revealed that the brain naturally prefers keywords that represent the big picture, as well as non-wordy sentences. This method is the best method for storing or remembering verbal images and ideas. Based on this statement, mind mapping can use as an alternative solution. Mind mapping can expand the main idea by creating several main branches. Through this main branch, additional information will be obtained in more detail from other branches (Edwards \& Cooper, 2010). Using a mind mapping framework will have several benefits, including students being able to use concept maps as a strategy for integrating new knowledge into prior knowledge, especially when they find it difficult to assimilate new knowledge (Greene \& Azevedo, 2010). By helping organize and organize knowledge, concept mapping not only allows the utilization of knowledge in new contexts or the transfer of knowledge but also the retention of knowledge that is more durable (Novak, 1990).

Concept mapping as a mind mapping framework facilitates meaningful learning for students. Meaningful knowledge gained from the two features that will be offered and is an advantage of the development carried out by researchers. Researchers offer features for students. They can determine themselves in choosing which sub material they do not understand. Then, they just click the trigger, and then the desired content appears. If they don't understand, they can get further detailed information, which is following the learning of mind mapping models.

Another feature is the exercise feature where students can calculate disposable income and income per capita automatically by entering the nominal numbers in the questions. This feature will be a differentiator between similar media and first exist.

The development of this media is based on the success of previous researchers in developing learning media. Based on research conducted by Setyawan (2015), the results of his study indicate that the developed mobile learning application can be one of the effective learning media for students. It hoped that the use of a smartphone in the school environment would have a positive impact, making it easier for students to obtain various learning resources (Pahrul, 2018). Research conducted by Farrokhnia et al. (2019) whose results also clearly reveal that mind mapping media is useful for enhancing students' conceptual understanding. Another study conducted by Abi-el-mona, I., \& Adb-El-Khalik (2006) also obtained results that the use of mind mapping can increase the value of students.

Based on the problems faced by teachers and students, researchers want to take advantage of technological developments to create appropriate learning media. This media built with the 
concept of mind mapping as a guide. It expected that this media could improve students' understanding of economic specialization about national income material.

\section{METHODS}

This research is Research and Development. Sugiyono (2017) states that research and development methods are research methods used to produce specific products and test the effectiveness of these products. The product developed in this research is the Android Based Mind Mapping Learning Media.

The development model used is Analyze, Design, Development, Implementation, and Evaluation which commonly abbreviated as ADDIE. According to Mulyatiningsih (2013), the ADDIE model can be utilized in various forms of product development, such as learning strategies, learning models, instructional media, and teaching materials. The ADDIE model chosen for several reasons, including it is a simple model, has clear, systematic research steps. This design illustrates a systematic approach to instructional development.

The research subjects were 36 students of class XI IPS 2 of SMA Negeri 1 Driyorejo. In this study, researchers used the One Group Pretest and Postest Design test strategy. According to Sugiyono (2015), the design of One Group Pretest and Posttest designs carried out using Pretest first, and then Postest implemented to find out the results.

The instrument in this study uses quantitative as well as qualitative data. Quantitative data is data in the form of numbers obtained from the results of the validation of media experts, expert experts on evaluation and student responses. Qualitative data collected from the results of the evaluation experts, material and media experts in the form of input as outlined in the study sheet. Criteria for the feasibility of the developed media can see in table 1.

Table 1. Validation Criteria

\begin{tabular}{ll}
\hline Percentages & Criteria \\
\hline $0-20 \%$ & Very Ineligible \\
$21-40 \%$ & Not Eligible \\
$41-60 \%$ & Are Decent Enough \\
$61-80 \%$ & Eligible \\
$81-100 \%$ & Very Worthy \\
\hline
\end{tabular}

Analysis of the validity of items was used to test the validity of each researcher problem, while reliability used to measure the questions to produce answers that were relatively consistent despite repeated measurements or different subjects. Validity is a measure that shows the level of validity and validity of an instrument (Arikunto, 2006), while Ghozali \& Fuad (2008) states that reliability is a tool to measure a questionnaire which is an indicator of variables or constructs. 
www.journal.univetbantara.ac.id/index.php/ijimm

A statistical difference test performed between the pretest and posttest values to prove an increase in students. This difference test method determined after checking the normality of the data. The t-test chose if the data normally distributed. If the data not normally distributed then the statistical test used is the Wilcoxson test. This test is one of the non-parametric tests which is very strong is an alternative to the t-test (Ghozali, 2006).

\section{RESULT AND DISCUSSION}

The development of instructional media is carried out systematically with ADDIE stages. Each stage that carried out is very related to the other steps. The first stage at the same time that most determine the success of media development is the stage of analysis. The output of this stage will determine how the design phase constructed. And so on until the media is ready to be used massively.

The analysis phase consists of an analysis of needs, competencies and learning objectives, and analysis of resources. Learning material delivered to achieve basic competencies to analyze the concepts and methods of calculating national income consists of 6 sub-chapters, namely: understanding national income, national income benefits, components of national income, methods of calculating national income, per capita income, and national income distribution.

Overall national income learning material there are material characteristics that require different understandings because there are material that is definitive, understanding concepts, and calculation applications. Competencies that expected to be acquired by students are divided into ten indicators. Each of these indicators can map in the revised version of Bloom's cognitive taxonomy level of cognitive ability (Anderson et al., 2001) .

The competency indicators included in the $\mathrm{C} 1$ level can identify the benefits of calculating national income and identify methods of calculating national income. Whereas at the $\mathrm{C} 2$ level, indicators are explaining the distribution of national income and explaining the meaning of per capita income.

Indicators at the C3 level are calculating a country's national income, calculating national income using three production approaches, and calculating a country's per capita income. For indicators at the $\mathrm{C} 4$ level, indicators are analyzing the concept of national income while the indicator at the C5 level is comparing Indonesia's per capita income with other countries.

The achievement of these learning objectives is very dependent on the level of student understanding gained from the learning process that they do. Also, the understanding of learning materials is related to the level of difficulty of the material that requires a different type of 
understanding. There are material indicators that only require an understanding of translation, interpretation, extrapolation (Sudjana, 2012).

The results of the study at this stage of the analysis found that students do not fully understand two indicators. These indicators are indicators of the ability of students to calculate income per capita and indicators of the ability of students to calculate national income in a country. This result was obtained from a limited test conducted on several students randomly.

The results of the resource analysis obtained information that the characteristics of class XI IPS 2 students at SMAN 1 Driyorejo totalling 36. Students numbered 12 men and 24 female students. The average age was 17 years. Most of them use cellular devices with the Android operating system. There are 33 of 36 students who use Android-based smartphones.

The next development stage is the design stage. This stage consists of content preparation and pre-production. Researchers conduct an inventory and design of material or content that will include in learning media. The material in this media is KD 3.1 material, namely analyzing the concept and method of calculating national income with the main focus being the indicator of calculating income per capita and national income. Other indicators also received attention, but with a reasonable proportion, both in terms of content, delivery method and practice.

Then the main content is determined and compiled, which consists of Home, Content Material, Quizzes, and Exercises. The main content than used as a basis for making an initial sketch of the application map so that in the development phase, the preparation of learning media is following the planned content. An example of one of these initial sketches shown in Figure 1. The design of the colour composition in the learning media supports the needs of the students, which will explain at the development stage.

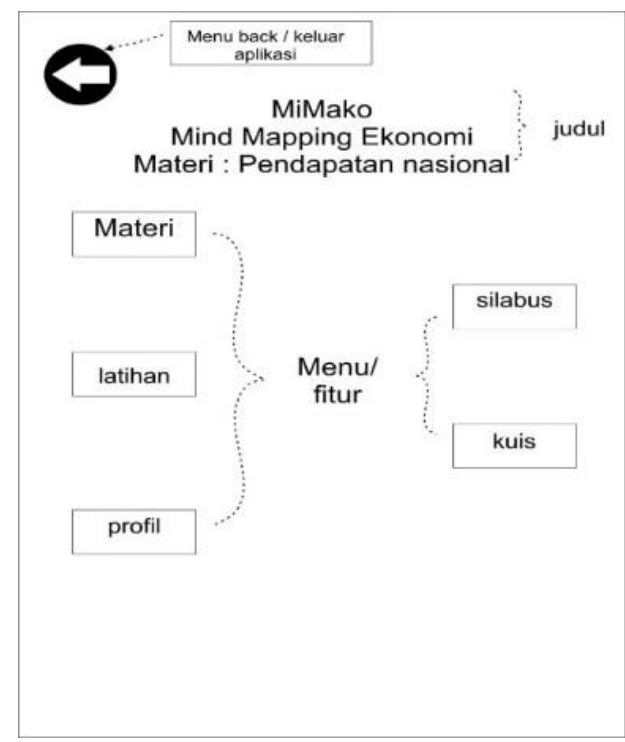

Figure 1. Initial sketch of the media 
The stages after the design are the stages of developing learning media applications. At this stage, the learning media production process carried out using the help of a unity application. The production process starts with the design analysis and then determines the colour composition of the Tosca colour theme. This colour was chosen because it is the majority choice of students after the poll. Psychologically the colour of Tosca or turquoise is a good colour to help concentration.

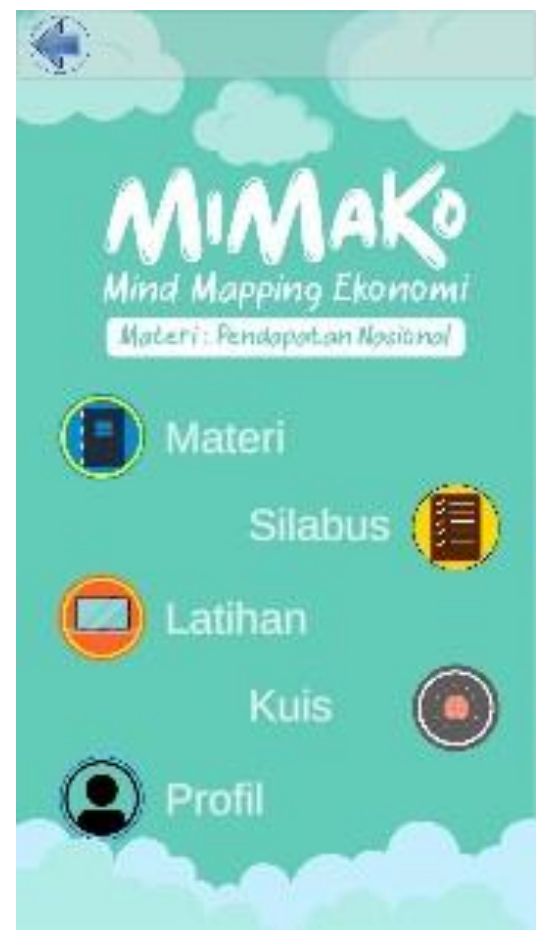

Figure 2. Home Display

The main menu design with the colour composition according to student preferences as in the homepage menu design in figure 2. This menu has to accommodate the main content with the addition of the developer profile. On the initial appearance, there is the title "MiMaKo" Mind Mapping Materi Ekonomi. Buttons to the main features are also placed here, namely the contents of the material, quizzes and exercises.

In the material content feature, there is national income material delivered based on the Mind Mapping channel. It contains an outline of national income material with three main material divisions. This design can see in Figure 3. In the three main material branches if touched (tap), one of them will appear a summary of material from each topic. The content of the material is also conveyed with a mind mapping framework. It is hoped that by using mind mapping students will associate the new information he gets into the structure of his knowledge. 
www.journal.univetbantara.ac.id/index.php/ijimm

Presentation of material using a mind mapping framework supported by Ausubel's meaningful learning theory. This theory introduces that learning is a human activity in building and creating meaningful knowledge under its knowledge. Packaging material with the concept of mind mapping also considers the conclusions of the research conducted by Abi-el-mona, I., \& Adb-El-Khalik (2006) who also uses mind mapping to increase students' understanding.

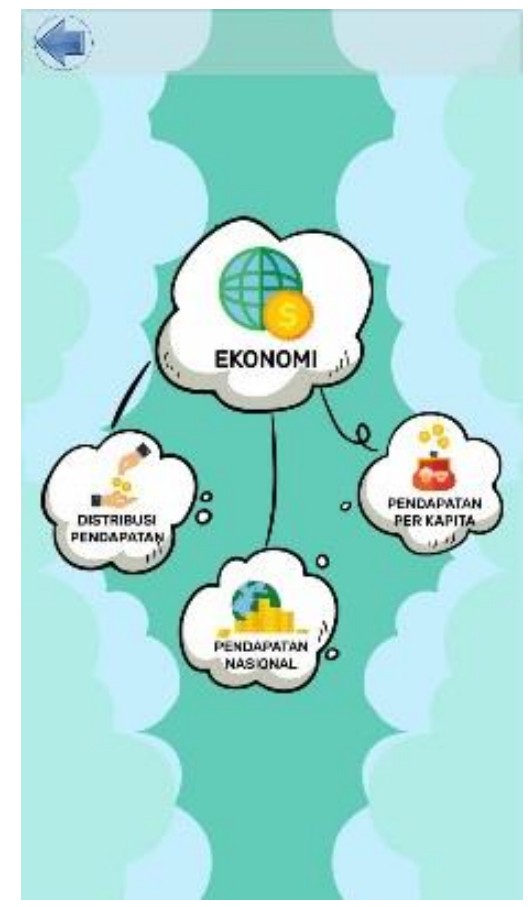

Figure 3. Display of Material Content Features

The material used to fill content in this media has validated by the material expert, one of the lecturers supporting the microeconomics course at Surabaya State University. This validation is critical to do because not all subject matter presented in this interactive media. A summary of the validation results from the material experts shown in table 2 . The validation results state that the material selected is suitable for use.

Table 2. Material Expert Validation

\begin{tabular}{lll}
\hline Validation Aspects & Score & Percentage \\
\hline Average of Content Quality and Objectives & 31 & $88 \%$ \\
Average of Instructional Quality & 28 & $93.3 \%$ \\
Average of Technical Quality & 23 & $92 \%$ \\
Average of Validation Results & 82 & $91 \%$ \\
\hline
\end{tabular}

After students learn interactively with a mind mapping framework students can try to answer the quizzes provided. The quiz features offered to help students know where they are learning. They can try to answer multiple-choice questions, then see the results of the answers 
www.journal.univetbantara.ac.id/index.php/ijimm

they provide as a form of an independent assessment that is part of the useful assessment as learning (Lee et al., 2019). The questions used in this quiz have also validated by one of the assessment expert lecturers at Surabaya State University. A summary of the results of the validation of the questions used presented in table 3. The average validation results reached $80 \%$. In general, the items used are appropriate to be used in this learning media.

Table 3. Evaluation Expert Validation

\begin{tabular}{lll}
\hline Validation Aspects & Score & Percentage \\
\hline Average Accuracy of KI and KD & 14 & $93 \%$ \\
Average Writing Items & 35 & $77 \%$ \\
Average Learning Process & 11 & $73.3 \%$ \\
Average Motivating Quality & 8 & $80 \%$ \\
Average of Validation Results & 68 & $80 \%$ \\
\hline
\end{tabular}

The questions and answers that appear on this feature deliberately randomized so that each student will receive a random question and cannot memorize the answer lock pattern. Randomization of questions and answers also intended so that students do not get bored when doing some repetition (Obergriesser \& Stoeger, 2020).

After finishing working on the problem, the value of the results given will appear. The questions totaled 15 pieces with an allocation of 20 minutes of work time overall. Examples of the appearance of the quiz can see in Figure 4. Thus students have a self-measuring tool that can use to determine the extent of their development. Finally, students can concentrate more on content that is not yet understood.

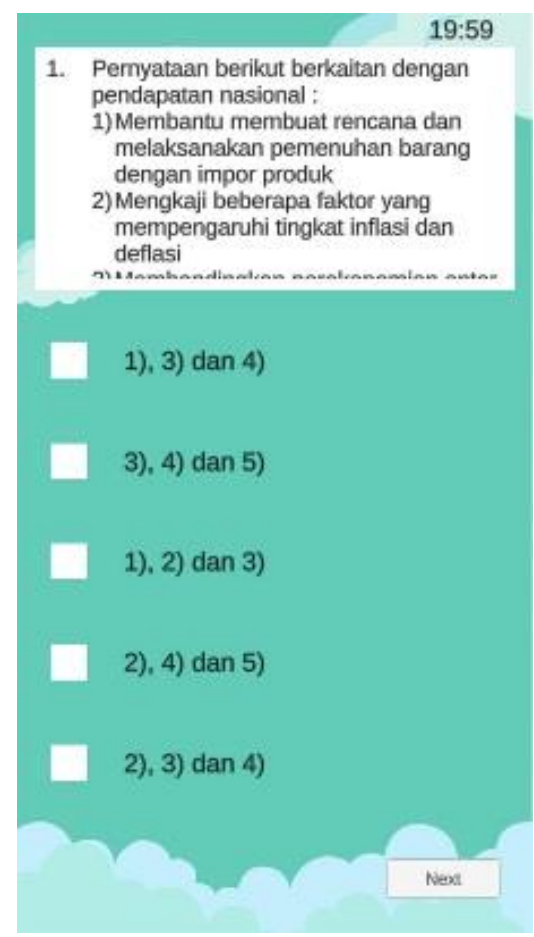

Figure 4. Display of Quiz Features 


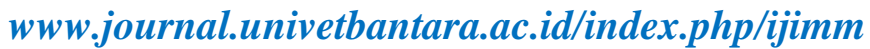

In addition to the quiz feature, practice features also provided. This feature is a response from the results of the analysis phase, which found that most students were unable to answer the questions of calculating national income. This feature selection as shown in figure 5. Through this feature, students can do simulations of calculating national income, disposable income, and income per capita. This exercise feature is also a differentiator with other similar learning media.

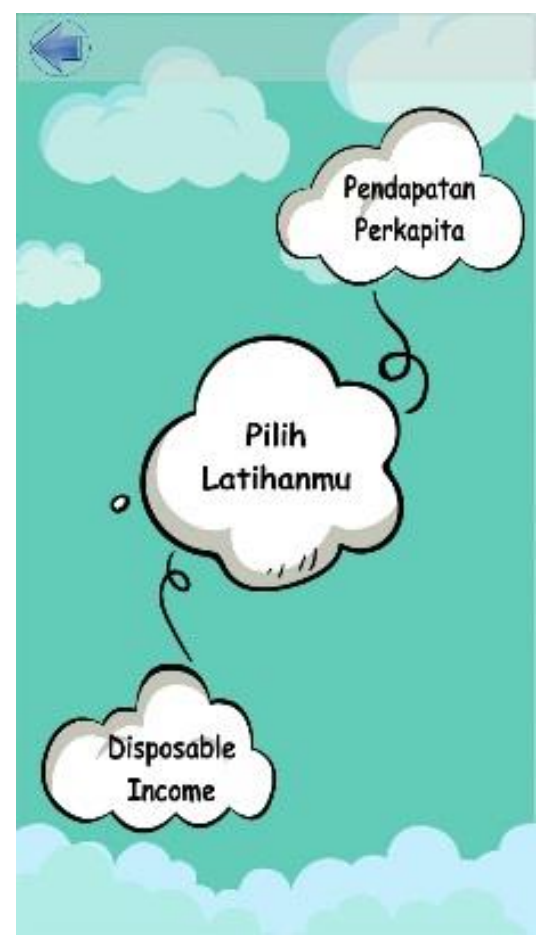

Figure 5. Display of Exercise Features

To ensure that the resources used in this media are appropriate for publication in the application market, such as the Google Play Store, then after the media built, it will be validated by media experts. This validation is also done to predict the level of product utility in learning. The validator requested to carry out the validation was one of the Lecturers of Learning Media at Surabaya State University. The results of the validation are presented in table 4. In general, the results of the validation of this media expert state that the media is appropriate for use.

Table 4. Learning Media Experts Validation

\begin{tabular}{lll}
\hline Validation Aspects & Score & Percentage \\
\hline Average of Content Quality and Objectives & 21 & $84 \%$ \\
Average of Instructional Quality & 19 & $95 \%$ \\
Average of Technical Quality & 47 & $85 \%$ \\
Average of Validation Results & 87 & $87 \%$ \\
\hline
\end{tabular}


www.journal.univetbantara.ac.id/index.php/ijimm

Once deemed feasible, the learning media is uploaded on the Google Play Console, which is then evaluated by the Google team. After passing the evaluation on the third day after submitting, the media is ready to be used and accessed by the public.

In the next stage, this learning media implemented in 36 students. Students must download the application in the google play store with the download link https://play.google.com/store/apps/details?id=com.Ramdan.MiMaKo, Apk installer also provided for those who do not want to download online. After students have successfully downloaded and installed it into their device, students can use the learning media to support their learning. At the implementation stage, it is expected to get a positive response from students, such as research conducted by Wijayanti \& Sumbawati (2018), which shows there is a relationship between learning outcomes with mobile media using mind mapping.

After the specified learning period, a simple evaluation will be carried out as a start to the last stage. At this stage, the researcher evaluates the media that have developed. The evaluation comes from two aspects, namely from the input of students and teachers as well as general user input that included in the Google Play Store comments and the developer email.

In general, students and teacher responses were very positive. They welcomed the presence of this learning media. Inputs received by researchers include the choice of quiz topics that do not yet exist. Some students want to work on problems with topics that they want to master. The number of question database in the quiz also needs to be added. Some propose that the quiz is made in stages or divided into several levels.

The responses of students are obtained from those who have used this learning media to support their learning. A total of 36 students were asked to fill in the response questionnaire. In general, their response was $87 \%$, which meant that students were very interested in this mind mapping learning media.

These results are in line with Chuang's (2014) suggestion that ICT learning media stimulates students to be actively involved, motivate learners' learning, and make classroom experiences more enjoyable. Another study conducted by Kiong et al. (2012) also shows that mind mapping developed has received positive responses from users.

Table 5. Items Validity

\begin{tabular}{cccc}
\hline Criteria & Question Item Number & Total & Percentage \\
\hline \multirow{2}{*}{ Valid } & 1,2, & & \\
& $3,5,6,7,8,11,12,13,14,15,16,17,21,22,24,25,26,28,29,30,31,32,33,3$ & 41 & $82 \%$ \\
Not Valid & $4,35,36,37,38,39,40,41,42,43,44,45,46,48,49,50$ & & \\
\hline & $4,9,10,18,19,20,23,27,47$ & 9 & $18 \%$ \\
\hline
\end{tabular}




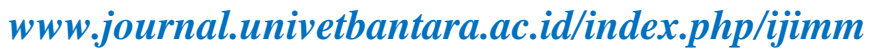

The contribution of the use of instructional media to increasing students' understanding is measured through differences in the results of pre and post-tests that have carried out. The pretest was done before students use Android-based mind mapping learning media, while the posttest did after the learning cycle is complete.

The questions used in the test analyzed for validity and reliability. In table 5 , it can see that there are 50 items tested for validity. There are 41 items declared valid, and nine items declared invalid. The results of the reliability analysis are summarized in table 6 , which shows that all indicators meet the reliability criteria on the basis that the Cronbach's Alpha value is greater than 0.6 so that it is declared reliable. To conduct a pre-test and post-test the researchers only used 30 items taken from items that were declared valid.

Table 6. Items Reliability

\begin{tabular}{ccc}
\hline Indicator & Question number & Cronbach's Alpha \\
\hline 1 & $1,2,3,5$ & 0,631 \\
2 & $6,7,8$ & 0,759 \\
3 & $11,12,13,14,15$ & 0,768 \\
4 & 16,17, & 0,658 \\
5 & $21,22,24,25$ & 0,672 \\
6 & $26,28,29,30$ & 0,821 \\
7 & $31,32,33,34,35$ & 0,805 \\
8 & $36,37,38,39,40$ & 0,894 \\
9 & $41,42,43,44,45$ & 0,772 \\
10 & $46,48,49,50$ & 0,730 \\
\hline
\end{tabular}

At the time of the pre-test, students get an average value of 44.4. while after the post-test, the average value of students increased to 75 . From both tests, it can seem that there was an increase in students' understanding by $30.6 \%$, as in table 7 .

Table 7. Pre-test and Post-test Results

\begin{tabular}{lcc}
\hline & Pre-test & Post-test \\
\hline Average & 44,4 & 75 \\
\hline
\end{tabular}

Statistical tests are needed to see the significance of these differences. The choice of statistical test techniques used needs to be seen in the distribution of the data first. If the data normally distributed, then the t-test is used, but if it not normally distributed, then the Wilcoxon test will be used.

Table 8. One-Sample Kolmogorov-Smirnov Test

\begin{tabular}{cccc}
\hline & Pre-test & \multicolumn{2}{c}{ Post-test } \\
\hline Asymp. Sig. (2-Tailed) & 0.922 & & 0.172 \\
\hline
\end{tabular}


The data normality test performed using the Kolmogorov-Smirnov One-Sample Test. The output of this test calculation presented in table 8 . A probability value of 0.172 indicates that the data normally distributed because $\alpha>0.05$.

Table 9. Paired Samples Test

\begin{tabular}{|c|c|c|c|c|c|c|c|c|c|}
\hline & & \multicolumn{5}{|c|}{ Paired Differences } & $\mathrm{T}$ & df & $\begin{array}{l}\text { Sig. }(2- \\
\text { tailed) }\end{array}$ \\
\hline & & \multirow[b]{2}{*}{ Mean } & \multicolumn{4}{|c|}{$\begin{array}{l}\text { 95\% Confidence Interval } \\
\text { of the Difference }\end{array}$} & & & \\
\hline & & & Deviation & Mean & Lower & Upper & & & \\
\hline Pair 1 & $\begin{array}{l}\text { Pre-test - } \\
\text { Post-test }\end{array}$ & -30.731 & 11.504 & 1.917 & -34.624 & -26.839 & -16.028 & 35 & 0.000 \\
\hline
\end{tabular}

After the data is declared normal, then t-test is performed. Based on the t-test results in table 9, it is known that $\mathrm{p}$-value $=0,000<\alpha=0.05$, which means that there are significant differences between students averages learning outcomes before and after using mind mapping learning media. Other research conducted by Liu et al. (2018) also shows that mind mapping can strengthen students' logical thinking and innovative thinking skills, motivate the development of students' lifelong learning thinking, and improve students' understanding. Other research that also strengthens this research is a study conducted by Buzan (2013) which states that mind mapping can improve students' understanding.

This result also confirms Squire's (2013) opinion, that the use of interactive media is considered capable of improving student learning outcomes. This Android-based mind mapping learning media is proven to improve students' understanding, such as the results of research that has been done by several previous researchers, such as Farrokhnia, et al. (2019) and Setyawan (2015).

\section{CONCLUSION}

Research in developing Android based mind mapping learning media using ADDIE development models has produced learning media products that are ready to use. Some critical components in this learning media have validated by experts in their fields and declared eligible for use. The results of product trials have proven that learning media can improve student understanding. The response given by students is also very positive, although there are still some shortcomings that will be fixed in the future. This research is again tested in a limited circle, to obtain information and further proof it is necessary to conduct a more stringent experiment and consider several confounding variables. 


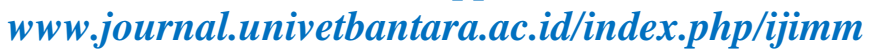

\section{REFERENCES}

Abi-el-mona, I., \& Adb-El-Khalik, F. (2006). The Influence of Mind Mapping on Eighth Graders' Science Achievement. School Science and Mathematics, 108(7), 298-312.

Anderson, L. W., Krathwohl, D. R., Airasian, P. W., Cruikshank, K. A., Mayer, R. E., Pintrich, P. R., ,.. Wittrock, M. C. (2001). A Taxonomy for Learning, Teaching, and Assessing: A Revision of Bloom's Taxonomyof Educational Objectives. New York: Addison Wesley Longman, Inc.

Arikunto, S. (2006). Metode Penelitian Kuantitatif. Jakarta: Bumi Aksara.

Buzan, T. (2013). How To Mind Map. London: Thorsons.

Calimag, J. N. V., Miguel, P. A. G., Conde, R. S., \& Aquino, L. B. (2014). Ubiquitous Learning Environment Using Android Mobile Aplication. International Journal of Research in Engineering \& Technology, Vol. 2(2), 119-128.

Chuang, Y.-T. (2014). Increasing Learning Motivation and Student Engagement through the TechnologySupported Learning Environment. Creative Education, 05(23), 1969-1978. https://doi.org/10.4236/ce.2014.523221

Dasna, I. W. (2015). Modul: Desain dan Model Pembelajaran Inovatif dan Interaktif, Universitas Terbuka,. (Online), ((https://repository.ut.ac.id/ 4324/1/MPDR5203-M1.pdf)), 1-61.

Edwards, S., \& Cooper, N. (2010). Mind mapping as a teaching resource, 236-239.

Farrokhnia, M., Pijeira-díaz, H. J., Noroozi, O., \& Hatami, J. (2019). Computer-supported collaborative concept mapping: The effects of different instructional designs on conceptual understanding and knowledge co-construction. Computers \& Education, 103640. https://doi.org/10.1016/j.compedu.2019.103640

Forment, arc A., \& Guerrero, M. J. C. (2008). Moodlbile: Extending Moodle to The Mobile On/Offline Scenario. IADIS International Conference Mobile Learning, 11-18.

Ghozali, I. (2006). Statistik Non-Parametrik-Teori dan Aplikasi dengan Program SPSS. Semarang: Badan Penerbit-Undip.

Ghozali, I., \& Fuad. (2008). Structural Equation Modeling. Teori, Konsep dan Aplikasi dengan Program LISREL 8.80. Semarang: BP-UNDIP.

Greene, J. A., \& Azevedo, R. (2010). The Measurement of Learners ' Self-Regulated Cognitive and Metacognitive Processes While Using Computer-Based Learning Environments The Measurement of Learners ' Self-Regulated Cognitive and Metacognitive Processes While Using Computer-Based Learning Envi. Educational Psychologist, (November 2014), 37-41. https://doi.org/10.1080/00461520.2010.515935

Kiong, T. T., Yunos, J. B. M., Mohammad, B. Bin, Othman, W. B., Heong, Y. M., \& Mohamad, M. M. B. (2012). The Development and Evaluation of the Qualities of Buzan Mind Mapping Module. Procedia - Social and Behavioral Sciences, 59(October), 188-196. https://doi.org/10.1016/j.sbspro.2012.09.264

Lee, I., Mak, P., \& Yuan, R. E. (2019). Assessment as learning in primary writing classrooms: An exploratory study. Studies in Educational Evaluation, 62, 72-81. https://doi.org/10.1016/j.stueduc.2019.04.012

Liu, Y., Tong, Y., \& Yang, Y. (2018). The Application of Mind Mapping into College Computer The Application of Mind Mapping into College Computer Programming Teaching Programming Teaching. Procedia Computer Science, 129, 66-70. https://doi.org/10.1016/j.procs.2018.03.047

Majid, A. (2014). Strategi Pembelajaran. Bandung: Remaja Rosdakarya.

Mulyatiningsih, E. (2013). Metode Penelitian Terapan Bidang Pendidikan. Bandung: Alfabeta.

Novak, J. D. (1990). Concept maps and Vee diagrams: two metacognitive tools to facilitate meaningful learning. Instructional Science, 52, 29-52.

Obergriesser, S., \& Stoeger, H. (2020). Students' emotions of enjoyment and boredom and their use of cognitive learning strategies - How do they affect one another? Learning and Instruction, 66, 101285. https://doi.org/10.1016/j.learninstruc.2019.101285

Pahrul. (2018). Dampak Penggunaan Smartphone (Studi Perilaku Sosial Siswa SMA Negeri Kecil Pulau Kulambing Kabupaten Pangkep).

Setyawan, A. (2015). Pengembangan Android Mobile Learning Menggunakan App Inventor Sebagai Media Pembelajaran Peserta Didik Kelas VII SMP/MTs.

Squire, K. (2013). Mobile media learning : multiplicities of place. https://doi.org/10.1108/10748120910936162

Sudjana, N. (2012). Dasar-Dasar Proses Belajar Mengajar. Bandung: SInar Baru Algesindo. 
www.journal.univetbantara.ac.id/index.php/ijimm

Sugiyono. (2015). Metode Penelitian dan Pengembangan (Research and Development / R\&D). Bandung: Penerbit Alfabeta.

Sugiyono. (2017). Metode Penelitian Kuantitatif, Kualitatif, dan R\&D. Bandung: Alfabeta.

Wijayanti, F., \& Sumbawati, M. S. (2018). Media Pembelajaran Mobile Dengan Menggunakan Mind Map Sebagai Motivasi Belajar Pada Mata Pelajaran Sistem Komputer di SMK Negeri 3 Buduran Sidoarjo, 03(2009). 